\title{
HUBUNGAN MODEL PEMBELAJARAN TUNTAS DAN METODE DISCOVERY TERHADAP MOTIVASI BELAJAR SISWA DI SIMA NEGERI 1 KUPANG
}

\author{
Asti Yunita Benu \\ Universitas Citra Bangsa Kupang \\ alriastitanebet@gmail.com \\ 082339559375
}

\begin{abstract}
The relationship of mastery learning models and methods of discovery due to the motivation to learn of students. Each student has a different motivation to learn inborn but is not ready to be a motivation to learn. One container to form a motivation to learn that is through education, namely concrete form through the learning process. But the learning process in the classroom is still dominated by the role of the teacher (teacher centered) and less precise methods used by teachers in teaching. More teachers putting students as objects and not as subjects students. This study aims to: (1) Knowing the relationship mastery learning model due to the formation of the motivation to learn of students at SMAN 1 Kupang, (2) Knowing the relationship discovery method to motivation to learn formation of students at SMAN 1 Kupang, (3) determine the relationship of mastery learning thoroughly and use methods discovery on motivation to learn formation of students at SMAN 1 Kupang. This research is a quantitative correlation using the questionnaire method. Mechanical testing data in this study is a reliability test questionnaire, questionnaire validity, normality test, homogeneity test and t-test statistics. The results of the analysis obtained after correlated, the first correlation between $X 1$ on $Y, t=2.819$ t table while the error level of 0,05$)=1.721 . \alpha 5 \%($ $0,05)=1.721$. The second correlation between $X 2$ on $Y, t=4.211$ t table while the error level of 5\% ( 0.05). The third correlation multiple correlation between X1, $X 2$ on Y obtained by $R$ of 0.67, F 12.77, $p=0.000>0,05$. Based on these calculations it can be concluded that (1) there is a positive and significant relationship between the variables of mastery learning models due to the motivation to learn of the student, (2) there is a positive and significant relationship between the variable method of discovery to the motivation to learn of students, and (3) there is a positive and significant relationship between the variables mastery learning models and methods of discovery due to the motivation to learn of students.
\end{abstract}

Keywords: learning model complete, discovery method and the motivation

\section{PENDAHULUAN}

\section{A. Latar Belakang}

Perubahan perilaku siswa sebagai hasil dari proses pembelajaran merupakan tujuan utama pendidikan. Sedangkan sebelum tercapainya perubahan perilaku, dalam proses pembelajaran perlu adanya motivasi dari siswa sendiri dalam belajar. Fenomena yang terjadi adalah proses pembelajaran di ruang kelas masih didominasi peran guru (teacher 
centered) dan kurang tepatnya metode yang digunakan guru dalam pembelajaran. Guru lebih banyak menempatkan siswa sebagai objek dan bukan sebagai subjek didik membuat siswa bosan dan kurang termotivasi. Masih ditemui dalam proses pendidikan dan pembelajaran di beberapa sekolah dewasa ini yang masih berjalan secara klasikal. Guru di dalam satu kelas menghadapi sejumlah besar siswa dalam jumlah waktu yang sama menyampaikan materi pembelajaran yang sama pula bahkan metodenyapun satu, metode yang sama untuk seluruh anak.

Perlakuan seperti inilah yang membuat siswa tidak memiliki motivasi untuk menjadikan belajar sebagai pengalaman yang menarik, yang dapat mengarahkannya untuk memahami sikap dan perilakunya. Dalam pembelajaran seperti ini guru telah beranggapan bahwa semua siswa dalam kelas tersebut mempuyai kemampuan, kesiapan dan kecepatan belajar yang sama. Padahal setiap siswa memiliki motivasi yang berbeda satu dengan yang lain. Ada siswa yang tingkat minat membacanya rendah, mempunyai bakat intelektual berbeda, mempunyai sikap mental yang berbeda, motivasi belajar yang berbeda dan kepribadian yang berbeda. Kenyataan yang ada tidak sesuai dengan harapan yang merupakan tujuan utama pendidikan. Setiap siswa melahirkan motivasi belajar dari dalam dirinya berbeda-beda. Salah satu wadah yang dapat membentuk motivasi yaitu melalui pendidikan. Bentuk konkrit pendidikan yaitu melalui proses pembelajaran. Proses pembelajaran yang masih didominasi guru juga terlihat di SMA Negeri 1 Kupang, kenyataan yang terjadi tidak berbeda dengan pendapat Shor dan Freire yang mengemukakan "guru seperti lampu senter, guru berjalan di dalam kelas kemudian melakukan provokasi pencerahan, seperti menghidupkan stop kontak listrik lalu keluar ruang dan akhirnya tugas selesai ditunaikan'. ' Jadi penting untuk disadari bahwa ada siswa yang belajar lebih efektif dan ada yang tidak. Ada yang lebih mudah mengerti dengan pendekatan visual, ada yang mudah menangkap verbal dan ada yang lebih cocok bila ada kegiatan praktek, latihan, aktivitas fisik atau simulasi.

Jadi pemilihan metode pembelajaranlah yang memberi peluang kepada siswa untuk menimbulkan atau melahirkan motivasi aktif dan kreatif dalam kegiatan pembelajaran adalah langkah awal yang utama menuju keberhasilan pembelajaran. Teori belajar kognitif mempelajari model dan proses mental seperti berpikir, mengingat dan memecahkan masalah yang muncul saat siswa memiliki motivasi dalam dirinya. Menurut Suryosubroto belajar tuntas adalah satu filsafat yang mengatakan bahwa dengan sistem pengajaran yang tepat semua siswa dapat belajar dengan hasil yang baik dari hampir seluruh materi pelajaran yang diajarkan di sekolah. ${ }^{2}$ Sehingga dengan model pembelajaran tuntas yang diterapkan guru di ruang kelas maka siswa memperoleh

\footnotetext{
${ }^{1}$ Freire P dan Shor I, Menjadi guru merdeka, (Yogyakarta: LKiS Yogyakarta, 1987), h. 176

${ }^{2}$ Suryosubroto. Proses Belajar Mengajar di Sekolah. (Jakarta: Rineka Cipta, 2002), h 96
} 
pengetahuan, dimana pencapaian ini sesuai dengan salah satu tujuan dari teori belajar kognitif yaitu siswa dapat memperoleh pengetahuan sebagai hasil dari proses belajar.

\section{B. Tujuan Penelitian}

Penelitian ini bertujuan untuk mengetahui hubungan model pembelajaran tuntas terhadap motivasi belajar siswa di SMA Negeri 1 Kupang, mengetahui hubungan metode discovery terhadap motivasi belajar siswa di SMA Negeri 1 Kupang dan mengetahui hubungan pembelajaran tuntas dan penggunaan metode discovery terhadap motivasi belajar siswa di SMA Negeri 1 Kupang. Selain itu penelitian ini diharapkan menjadi bahan referensi yang dapat memberikan informasi tentang usaha yang harus dilakukan guru dalam memotivasi siswa dalam proses belajar demi mencapai tujuan pendidikan yang diharapkan.

\section{KAJIAN TEORI}

\section{A. Model Pembelajaran Tuntas}

Rusman mengemukakan bahwa pembelajaran adalah proses interaksi peserta didik dengan guru dan sumber belajar pada suatu lingkungan belajar. Proses pembelajaran perlu direncanakan, dilaksanakan, dinilai dan diawasi agar terlaksana secara efektif dan efisien. ${ }^{3}$ Model pembelajaran adalah suatu rencana atau pola yang dapat digunakan untuk membentuk kurikulum (rencana pembelajaran jangka panjang), merancang bahan-bahan pembelajaran dan membimbing pembelajaran di kelas atau yang lain (Joyce dan Weil). ${ }^{4}$ Sedangkan menurut Rusman sendiri model pembelajaran dapat dijadikan pola pilihan, artinya para guru boleh memilih model pembelajaran yang sesuai dan efisien untuk mencapai tujuan pendidikannya. Sehingga dapat disimpulkan bahwa model pembelajaran merupakan pola umum perilaku pembelajaran untuk mencapai tujuan pembelajaran yang diharapkan. Pembelajaran merupakan kegiatan dimana keterlibatan individu anak didik mutlak adanya, apabila tidak ada anak didik atau obyek didik, siapa yang akan diajar. Hal ini perlu disadari guru agar tidak terjadi kesalahan tafsir terhadap kegiatan pembelajaran. Karena itu, belajar dan pembelajaran merupakan istilah yang sudah baku dan nyata dalam konsep pembelajaran atau pendidikan, biasanya permasalahan yang guru hadapi ketika berhadapan dengan sejumlah anak didik adalah masalah pengelolaan kelas, apa, siapa, bagaimana, kapan, dan di mana adalah pertanyaan yang dijawab dalam hubungannya dengan masalah.

Belajar tuntas adalah satu filsafat yang mengatakan bahwa dengan sistem pengajaran yang tepat semua siswa dapat belajar dengan hasil yang baik dari hampir

${ }^{3}$ Rusman. Model-model Pembelajaran: Mengembangkan profesionalisme guru. (Jakarta: Rajawali Pers, 2012), h. 3

${ }^{4}$ Rusman. Model-model Pembelajaran: Mengembangkan profesionalisme guru. (Jakarta: Rajawali Pers, 2012), h. 133 
seluruh materi pelajaran yang diajarkan di sekolah. ${ }^{5}$ Menurut Elliot dalam Khodijah, salah satu cara yang dapat ditempuh oleh guru untuk mengatasi perbedaan individual siswa adalah dengan penerapan mastery learning, yaitu suatu kualitas pembelajaran di mana guru dan siswa memutuskan secara bersama tentang waktu yang dibutuhkan dan apa yang perlu dikuasai oleh siswa. ${ }^{6}$

Salah satu cara yang dapat ditempuh untuk mengatasi perbedaan motivasiistik siswa adalah dengan menerapkan mastery learning (pembelajaran tuntas). Mastery learning memungkinkan siswa untuk menyelesaikan materi pembelajaran sesuai dengan kemampuan dan motivasi masing-masing. Tidak semua siswa mampu menguasai materi pembelajaran dalam waktu yang sama. Perbedaan individual merupakan hal yang pasti dijumpai dalam kondisi pembelajaran di manapun. Strategi belajar tuntas dapat dibedakan dari pengajaran non belajar tuntas terutama dalam hal-hal berikut ini:

1. Pelaksanaan tes secara teratur untuk memperoleh umpan balik terhadap bahan yang diajarkan sebagai alat untuk mendiagnosa kemajuan.

2. Peserta didik baru dapat melangkah pada pelajaran berikutnya setelah ia benarbenar menguasai bahan pelajaran sebelumny sesuai dengan patokan yang ditetapkan.

3. Pelayanan bimbingan dan penyuluhan terhadap anak didik gagal mencapai taraf penguasaan penuh, melalui pengajaran korektif, yang menurut Morrison merupakan pengajaran kembali, pengajaran tutorial, restrukturasi kegiatan belajar dan pengajaran kembali kebiasaan-kebiasaan belajar peserta didik, sesuai dengan waktu yang diperlukan masing-masing. ${ }^{7}$

Model belajar tuntas dapat diterapkan secara tuntas untuk meningkatkan kualitas pendidikan. Banyamin. S. Bloom (1968) menyebutkan 3 strategi dalam belajar tuntas yaitu mengidentifikasi prakondisi, mengembangkan prosedur operasional dan hasil belajar, selanjutnya mengimplementasikan dalam pembelajaran kalsikal dengan memberikan "bumbu" untuk menyesuaikan dengan kemampuan individual, yang meliputi:

1. Corrective Technique. Pengajaran remedial, yang dilakukan dengan memberikan pengajaran terhadap tujuan yang gagal dicapai oleh peserta didik, dengan prosedur dan metode yang berbeda dari sebelumnya.

\footnotetext{
${ }^{5}$ Suryosubroto. Proses Belajar Mengajar di Sekolah. (Jakarta: Rineka Cipta, 2002), h 96

${ }^{6}$ Khodijah, Nyayu. Psikologi Pendidikan. (Palembang: Grafika Telindo Press, 2011), h. 191

${ }^{7}$ Mulyasa. Implementasi Kurikulum 2004 Panduan Belajar KBK.( Bandung: Remaja Rosdakarya,
} 2004), h. 155 
2. Memberikan tambahan waktu kepada peserta didik yang membutuhkan (belum menguasai bahan secara tuntas) ${ }^{8}$

Khodijah menambahkan bahwa suatu pembelajaran dikatakan berhasil bila mencapai hasil yang diharapkan. ${ }^{9}$ Sedangkan untuk mencapai hasil yang diharapkan, guru perlu menggerakan siswa agar memiliki motivasi dalam proses belajar. Apabila pembelajaran tuntas dilakukan dalam kondisi yang tepat maka semua peserta didik memiliki motivasi, mampu belajar dengan baik dan memperoleh hasil yang maksimal terhadap seluruh materi yang dipelajari. Siswa yang sudah dimasukkan ke dalam alat pemrosesan, yaitu transformasi atau proses dan sudah menjadi bahan jadi, dikenal dengan istilah hasil atau keluaran (output). ${ }^{10}$

Secara mudah dapat dikatakan bahwa hasil pembelajaran adalah siswa yang telah menjadi bahan jadi setelah melalui tahapan transformasi atau pemrosesan, yaitu kegiatan belajar mengajar. Sehingga kualitas proses pembelajaran sangat penting untuk memperoleh hasil yang baik. Dapat disimpulkan bahwa pengkajian terhadap pengukuran proses pembelajaran dapat dilakukan dengan memperhatikan motivasi belajar, bentuk perubahan tingkah laku, pengaplikasian dalam kehidupan, tahan lama diingat dan inilah yang disebut sebagai motivasi yang terbentuk melalui proses pembelajaran.

Menurut Bloom (1971) dalam Suryosubroto, yang mengembangkan model belajar tuntas ini, beberapa implikasi belajar tuntas disebutkan sebagai berikut:

1. dengan kondisi optimal, sebagian besar siswa dapat menguasai pelajaran secara tuntas

2. guru bertugas mencari setiap kemungkinan untuk menciptakan kondisi yang optimal termasuk waktu, metode, media serta umpan balik untuk siswa

3. siswa adalah individu-individu yang berbeda, oleh karena itu kondisi optimal bagi masing-masing siswa berbeda

4. siswa seharusnya mengerti hakikat, tujuan serta prosedur belajar

5. sangat bermanfaat bila pelajaran diperinci dalam satuan-satuan pelajaran yang kecil dan selalu diadakan tes pada akhir satuan pelajaran

6. kegiatan belajar akan lebih efektif bila siswa membentuk kelompok-kelompok belajar yang kecil yang dapat bertemu secara teratur untuk saling membantu mengatasi kesulitan

\footnotetext{
${ }^{8}$ Yamin Martinis. Profesionalisasi Guru dan Implementasi Kurikulum Berbasis Kompetensi. (Jakarta: Gaung Persada Press, 2006), h 121-122)

${ }^{9}$ Khodijah, Nyayu. Psikologi Pendidikan. (Palembang: Grafika Telindo Press, 2011), h. 199

${ }^{10}$ Arikunto Suharsimi. Dasar-Dasar Evaluasi Pendidikan. (Jakarta: Bumi Aksara, 2009), h. 295
} 
7. penilaian akhir harus didasarkan atas tingkat penguasaan tujuan instruksional khusus pelajaran yang bersangkutan ${ }^{11}$

\section{B. Metode Diccovery}

Sagala, mengemukakan bahwa hal yang penting dalam metode ialah bahwa setiap metode pembelajaran yang digunakan bertalian dengan tujuan belajar yang ingin dicapai. Discovery adalah proses mental dimana siswa mengasimilasikan sesuatu konsep atau sesuatu prinsip. ${ }^{12}$ Proses mental tersebut misalnya: mengamati, menggolong-golongkan, membuat dugaan, menjelaskan, mengukur, membuat kesimpulan dan sebagainya (Sound dalam Suryosubroto). ${ }^{13}$ Jadi dengan metode pembelajaran ini, motivasi belajar siswa akan lebih mudah muncul. Peranan guru lebih banyak menetapkan diri sebagai pembimbing atau pemimpin belajar dan fasilitator belajar. Metode discovery merupakan pendekatan mengajar yang berusaha meletakan dasar dan mengembangkan cara berpikir ilmiah, metode ini menempatan siswa belajar sendiri, mengembangkan kekreatifan dalam memecahan masalah.

Metode penemuan diartikan sebagai suatu prosedur mengajar yang mementingkan pengajaran perseorangan, manipulasi objek dan lain-lain percobaan sebelum sampai kepada generalisasi. ${ }^{14}$ Metode penemuan merupakan komponen dari praktek pendidikan yang meliputi metode mengajar yang memajukan cara belajar aktif, berorientasi pada proses, mengarahkan sendiri, mencari sendiri dan reflektif. Tujuan dari penggunaan metode pembelajaran penemuan adalah untuk membuat siswa memiliki pemahaman yang mendalam melalui keterlibatan secara aktif dalam menempuh proses belajar. ${ }^{15}$ Sedangkan menurut Burner dalam Mulyatiningsih, discovery learning merupakan metode pembelajaran kognitif yang menuntut guru lebih kreatif menciptakan situasi yang dapat membuat peserta didik belajar aktif menemukan pengetahuan sendiri. ${ }^{16}$

Metode pembelajaran discovery berorientasi pada pendekatan pembelajaran berbasis masalah dan teori belajar yang melandasinya adalah teori belajar bermakna dari David Ausubel, belajar bermakna merupakan proses belajar dimana informasi baru dihubungkan dengan struktur pengertian yang sudah dimiliki seseorang yang sedang belajar. Menurut Dahar (1989) dalam Rusman mengemukakan bahwa metode penemuan

\footnotetext{
${ }^{11}$ Suryosubroto. Proses Belajar Mengajar di Sekolah. (Jakarta: Rineka Cipta, 2002), h.112

${ }^{12}$ Sagala Syaiful. Konsep dan Makna Pembelajaran. (Bandung: Alfabeta, 2010), h. 201

${ }^{13}$ Suryosubroto. Proses Belajar Mengajar di Sekolah. (Jakarta: Rineka Cipta, 2002), h.193

${ }^{14}$ Suryosubroto. Proses Belajar Mengajar di Sekolah. (Jakarta: Rineka Cipta, 2002), h.192

${ }^{15}$ Pribadi Benny. Model ASSURE untuk Mendesain Pembelajaran Sukses. (Jakarta: Dian
} Rakyat, 2011), h. 82

${ }^{16}$ Mulyatiningsih Endang. Metode Penelitian Terapan Bidang Pendidikan. (Bandung: Alfabeta, 2012), h 235 
merupakan metode dimana siswa menemukan kembali, bukan menemukan yang sama sekali benar-benar baru. Belajar penemuan sesuai dengan pencarian pengetahuan secara aktif oleh manusia, dengan sendirinya memberikan hasil yang lebih baik, berusaha sendiri mencari pemecahan masalah serta didukung oleh pengetahuan yang menyertainya, serta menghasilkan pengetahuan yang benar-benar bermakna. ${ }^{17}$ Menurut Mulyatiningsih sendiri, discovery learning merupakan strategi yang digunakan untuk memecahkan masalah secara intensif di bawah pengawasan guru. ${ }^{18}$

Dari beberapa pendapat ini dapat disimpulkan bahwa discovery adalah suatu metode dimana dalam proses belajar mengajar guru memperkenankan siswa menemukan sendiri informasi yang secara tradisional biasa diberitahukan atau diceramahkan saja dengan memperhatikan langkah-langkah dalam metode ini.

Pada dasarnya siswa bukan pembisu, mereka memiliki masalah besar yang ingin disampaikannya tetapi tidak di dalam pola naskah ruang kelas tradisional. ${ }^{19}$ Sehingga dengan menerapkan salah satu metode pembelajaran yaitu metode discovery, guru memberi kesempatan kepada siswa untuk belajar aktif dan belajar menemukan sendiri sehingga dengan sendirinya motivasi siswa untuk belajar semakin muncul.

Ada 7 kelebihan dari metode pembelajaran discovery yaitu:

a. Teknik ini mampu membantu siswa untuk mengembangkan; memperbanyak kesiapan serta penguasaan ketrampilan dalam proses kognitif/pengenalan siswa. siswa memperoleh pengetahuan yang bersifat sangat pribadi sehingga mendalam tertinggal dalam jiwa siswa tersebut

b. Dapat membangkitkan kegairahan belajar siswa

c. Teknik ini mampu memberikan kesempatan kepada siswa untuk berkembang dan maju sesuai dengan kemampuannya masing-masing

d. Mampu mengarahkan cara siswa belajar sehingga lebih memiliki motivasi yang kuat untuk belajar lebih giat

e. Membantu siswa untuk memperkuat dan menambah kepercayaan pada diri sendiri dengan proses penemuan sendiri

f. Strategi ini berpusat pada siswa tidak pada guru. Guru hanya sebagai teman belajar saja: membantu bila diperlukan. ${ }^{20}$

17 Rusman. Model-model Pembelajaran: Mengembangkan profesionalisme guru. (Jakarta: Rajawali Pers, 2012), h. 245

${ }^{18}$ Mulyatiningsih Endang. Metode Penelitian Terapan Bidang Pendidikan. (Bandung: Alfabeta, 2012), h 235

\footnotetext{
${ }^{19}$ Freire P dan Shor I, Menjadi guru merdeka, (Yogyakarta: LKiS Yogyakarta, 1987), h 180

${ }^{20}$ Roestiyah. Strategi Belajar Mengajar. (Jakarta: Rineka Cipta, 2008), h. 21
} 


\section{Motivasi Belajar}

Motivasi sebagai proses di dalam diri individu yang aktif, mendorong, memberikan arah dan menjaga perilaku setiap saat. Motivasi juga diartikan sebagai pengaruh kebutuhan-kebutuhan dan keinginan terhadap intensitas dan arah perilaku seseorang. ${ }^{21}$ Sementara itu, Sardiman berpendapat bahwa dalam kegiatan belajar, motivasi dapat dikatakan sebagai keseluruhan daya penggerak di dalam diri siswa yang menimbulkan, menjamin kelangsungan dan memberikan arah kegiatan belajar, sehingga diharapkan tujuan dapat tercapai. ${ }^{22}$ Motivasi juga memiliki peranan yang penting dalam proses belajar, sebab motivasi berperan sebagai penguat belajar, memperjelas tujuan belajar dan menentukan ketekunan belajar.

Selain itu didukung pula oleh pendapat Sardiman bahwa seseorang akan berhasil dalam belajar, kalau pada dirinya sendiri ada keinginan untuk belajar, keinginan atau dorongan untuk belajar inilah yang disebut dengan motivasi. Motivasi diperlukan dalam menentukan intensitas usaha belajar bagi para siswa. ${ }^{23}$ Sedangkan menurut Djamarah ada tiga fungsi motivasi, yakni :

a. Motivasi sebagai pendorong perbuatan. Motivasi berfungsi sebagai pendorong untuk mempengaruhi sikap apa yang seharusnya anak didik ambil dalam rangka belajar

b. Motivasi sebagai penggerak perbuatan. Dorongan psikologis melahirkan sikap terhadap anak didik itu merupakan suatu kekuatan yang tak terbendung,yang kemudian terjelma dalam bentuk gerakan psikofisik

c. Motivasi sebagai pengarah perbuatan. Anak didik yang mempunyai motivasi dapat menyeleksi mana perbuatan yang harus dilakukan dan perbuatan yang perlu diabaikan ${ }^{24}$

Guru harus mampu mengelolah pembelajaran aktif, kreatif dan inovatif yang dapat menimbulkan atau melahirkan atau memunculkan motivasi belajar siswa. Upaya yang dapat dilakukan oleh seorang guru menurut Dimyati yaitu dengan cara :

a. Memberi kesempatan kepada siswa untuk mengungkapkan hambatan belajar yang di alaminya

b. Meminta kesempatan kepada orang tua siswa agar memberikan kesempatan kepada siswa untuk beraktualisasi diri dalam belajar

c. Memanfaatkan unsur-unsur lingkungan yang mendorong belajar

\footnotetext{
${ }^{21}$ Wahab, Rohmalina. Psikologi Belajar. (Jakarta: PT Raja Grafindo Persada, 2015), h. 28

${ }^{22}$ Sardiman A. M. Interaksi dan Motivasi Belajar Mengajar. Jakarta: Rajawali Pers, 2014), h. 75

${ }^{23}$ Sardiman A. M. Interaksi dan Motivasi Belajar Mengajar. Jakarta: Rajawali Pers, 2014), h. 40

${ }^{24}$ Djamarah. Strategi Belajar Mengajar. (Jakarta : Rineka Cipta, 2002), h. 123
} 
d. Menggunakan waktu secara tertib, penguat dan suasana gembira terpusat pada perilaku belajar

e. Merangsang siswa dengan penguat memberi rasa percaya diri bahwa ia dapat mengatasi segala hambatan dan pasti berhasil

f. Guru mengoptimalisasikan pemanfataan pengalaman dan kemampuan siswa ${ }^{25}$

Lemahnya motivasi atau tiadanya motivasi belajar akan melemahkan kegiatan, sehingga mutu hasil belajar menjadi rendah. Oleh karena itu, motivasi belajar pada diri siswa perlu diperkuat terus menerus. Dengan tujuan agar siswa mempunyai motivasi belajar yang kuat, sehingga hasil belajar yang diraihnya dapat optimal.

\section{METODE PENELITIAN}

Jenis penelitian ini adalah penelitian kuantitatif korelasi. Penelitian korelasional bertujuan mengungkapkan hubungan korelatif antar variabel, Hubungan korelatif mengacu pada kecenderungan bahwa variasi suatu variabel diikuti variasi variabel yang lain. Yang menjadi populasi dalam penelitan ini yaitu siswa kelas XI SMA Negeri 1 Kupang. Untuk memperoleh data yang diperlukan peneliti menggunakan dua teknik atau cara pengumpulan data yaitu angket dan observasi. Teknik pengujian data dalam penelitian ini menggunakan uji validatas dan uji reliabilitas. Uji validitas angket digunakan untuk menguji apakah butir instrument valid atau tidak menggunakan rumus korelasi product moment. Sedangkan untuk uji reliabilitas digunakan rumus alpha. ${ }^{26}$ Selanjutnya sebelum data dianalisis terlebih dahulu dilakukan juga uji homogenitas dan uji normalitas. Sedangkan dalam analisis data yang dilakukan untuk mencari derajat hubungan menggunakan perhitungan korelasi, mencari koefisian determinasi, mencari nilai korelasi ganda dan selanjtnya mencari $t$ hitung dan $t$ table.

\section{HASIL DAN PEMBAHASAN}

\section{A. Hasil}

1. Uji Normalitas dan Uji Homogenitas

Uji normalitas dilakukan untuk mengetahui apakah data tiga variabel penelitian berasal dari data yang berdistribusi secara normal atau tidak. Sedangkan uji homogenitas untuk mengetahui apakah data berasal dari populasi yang homogen atau tidak. Teknik pengujian normalitas menggunakan perhitungan Chi-Kuadrat sedangkan teknik pengujian homogenitas menggunakan perhitungan Levene test sehingga memperoleh hasil sebagai berikut:

\footnotetext{
${ }^{25}$ Dimyati, Mudjiono. Belajar dan Pembelajaran. Jakarta: Rineka Cipta, 2002), h. 95

${ }^{26}$ Kasmadi dan Nia Siti Sunariah. Panduan Modern Penelitian Kuantitatif. Bandung: Alfabeta, 2013), h. 79
} 
a. Uji normalitas

Tabel 4.1

Tabel hasil perhitungan uji normalitas

Test Statistics

\begin{tabular}{|l|r|r|r|}
\hline & \multicolumn{1}{|c|}{$\mathrm{X} 1$} & \multicolumn{1}{|c|}{$\mathrm{X} 2$} & \multicolumn{1}{c|}{$\mathrm{Y}$} \\
\hline Chi-Square & $8.000^{\mathrm{a}}$ & $2.917^{\mathrm{b}}$ & $5.000^{\mathrm{a}}$ \\
Df & 11 & 18 & 11 \\
Asymp. Sig. & .713 & 1.000 & .931 \\
\hline
\end{tabular}

a. 12 cells $(100,0 \%)$ have expected frequencies less than 5 . The minimum expected cell frequency is 2,0 .

b. 19 cells $(100,0 \%)$ have expected frequencies less than 5 . The minimum expected cell frequency is 1,3 .

Berdasarkan pengujian normalitas diperoleh harga sig. variabel Y sebesar 0,931. Sedangkan harga sig. variabel X1 sebesar 0,713 dan harga sig. variabel X2 sebesar 1,000. Dari hasil pengujian dapat diperhatikan bahwa seluruh data signifikansi berada di atas harga sig $>0,05$. Hal ini memberi kesimpulan bahwa seluruh data instrumen variabel bebas dan terikat berdistribusi secara normal.

b. Uji Homogenitas

Tabel 4.2

Tabel hasil perhitungan uji homogenitas

Test of Homogeneity of Variances

\begin{tabular}{|l|r|r|r|r|}
\hline & $\begin{array}{l}\text { Levene } \\
\text { Statistic }\end{array}$ & df1 & df2 & Sig. \\
\hline X1 & 2.062 & 7 & 12 & .129 \\
& 3.749 & 7 & 12 & .022 \\
\hline
\end{tabular}

Berdasarkan pengujian homogenitas diperoleh harga sig. variabel X1 sebesar 0,129 dan harga sig. variabel X2 sebesar 0,022. Dari hasil pengujian dapat diperhatikan bahwa seluruh data signifikansi berada di atas harga sig $>0,05$. Hal ini memberi kesimpulan bahwa seluruh data instrumen variabel bebas dan terikat bersifat homogen. 
2. Uji Reliabilitas Angket

Uji reliabilitas angket dilakukan untuk mengukur tingkat kepercayaan atau reliabilitas instrumen. Suatu instrumen dikatakan reliabel apabila hasil pengukuran dengan alat tersebut adalah sama jika sekiranya pengukuran tersebut dilakukan pada orang yang sama pada waktu yang berlainan atau pada kelompok orang yang berlainan pada waktu yang sama. Uji validitas angket dalam penelitian ini dilakukan pada semua variabel (terikat dan bebas) dengan menggunakan rumus korelasi alpha cronbach sehingga diperoleh hasil sebagai berikut:

1. Variabel model pembelajaran tuntas

Tabel 4.3

Tabel hasil perhitungan uji reliabilitas variabel model pembelajaran tuntas

\section{Reliability Statistics}

\begin{tabular}{|c|c|}
\hline Cronbach's Alpha & N of Items \\
\hline .743 & 22 \\
\hline
\end{tabular}

Dari hasil perhitungan statistik menunjukan nilai alpha adalah 0,743. Berdasarkan nilai acuan pada tabel 4.7 maka instrumen angket mempunyai koefisien korelasi sangat kuat karena di atas 0,80. Dengan demikian angket yang digunakan untuk model pembelajaran tuntas berjumlah 22 item.

2. Variabel metode discovery

Tabel 4.4

Tabel hasil perhitungan uji reliabilitas variabel metode discovery

Reliability Statistics

\begin{tabular}{|c|c|}
\hline Cronbach's Alpha & N of Items \\
\hline .753 & 25 \\
\hline
\end{tabular}

Dari hasil perhitungan statistik menunjukan nilai alpha adalah 0,753. Berdasarkan nilai acuan pada tabel 4.8 maka instrumen angket mempunyai koefisien korelasi sangat kuat karena di atas 0,80. Dengan demikian angket yang digunakan untuk variabel metode discovery berjumlah 25 item. 
3. Variabel motivasi siswa

Tabel 4.5

Tabel hasil perhitungan uji reliabilitas variabel motivasi siswa

\section{Reliability Statistics}

\begin{tabular}{|c|c|}
\hline Cronbach's Alpha & N of Items \\
\hline .750 & 22 \\
\hline
\end{tabular}

Dari hasil perhitungan statistik menunjukan nilai alpha adalah 0,750. Berdasarkan nilai acuan pada tabel 4.9 maka instrumen angket mempunyai koefisien korelasi sangat kuat karena di atas 0,80. Dengan demikian angket yang digunakan untuk variabel motivasi siswa berjumlah 22 item.

\section{B. Teknik Analisis Data}

Mencari derajat hubungan menggunakan korelasi pearson product moment

Teknik korelasi digunakan untuk mencari hubungan dan membuktikan hipotesis hubungan dua variabel bila data kedua variabel berbentuk interval atau ratio, dan sumber data dari dua variabel atau lebih tersebut adalah sama (Sugiyono, 2012:228).

1. Hubungan variabel X1 (model pembelajaran tuntas) terhadap Y (motivasi siswa).

Berdasarkan perhitungan yang diperoleh dengan menggunakan rumus:

$$
\begin{aligned}
& \operatorname{rxy}= \frac{\mathrm{n} \sum \mathrm{X}_{1} \mathrm{Y}-\left(\sum \mathrm{X}_{1}\right)\left(\sum \mathrm{Y}_{1}\right)}{\sqrt{\left\{\mathrm{n} \sum \mathrm{X}_{1}{ }^{2}-\left(\sum \mathrm{X}_{1}\right)^{2}\right\}\left\{\mathrm{n} \sum \mathrm{Y}_{1}{ }^{2}-\left(\sum \mathrm{Y}_{1}\right)^{2}\right\}}} \\
&= \frac{24(108780)-(1532)(1698)}{\sqrt{\left(24(98032)-(1532)^{2}\right)\left(24(121646)-(1698)^{2}\right)}} \\
&=\frac{2610720-2601336}{\sqrt{(2352768-2347024)(2919504-2883204)}} \\
&=\frac{9384}{\sqrt{(5744)(36300)}} \\
&=\frac{9384}{\sqrt{208507200}} \\
&=\frac{9384}{14439,77839} \\
&=0,64987
\end{aligned}
$$

2. Hubungan variabel X2 (metode discovery) terhadap Y (motivasi siswa).

Berdasarkan perhitungan yang diperoleh dengan menggunakan rumus:

$$
\operatorname{rxy}=\frac{\mathrm{n} \sum \mathrm{X}_{2} \mathrm{Y}-\left(\sum \mathrm{X}_{2}\right)\left(\sum \mathrm{Y}_{\mathrm{i}}\right)}{\sqrt{\left\{\mathrm{n} \sum \mathrm{X}_{2}{ }^{2}-\left(\sum \mathrm{X}_{2}\right)^{2}\right\}\left\{\mathrm{n} \sum \mathrm{Y}_{\mathrm{i}}{ }^{2}-\left(\sum \mathrm{Y}_{\mathrm{i}}\right)^{2}\right\}}}
$$




$$
\begin{aligned}
=\frac{24(118677)-(1673)(1698)}{\sqrt{\left(24(117189)-(1673)^{2}\right)\left(24(121646)-(1698)^{2}\right)}} \\
=\frac{2848248-2840754}{\sqrt{(2812536-2798929)(2919504-2883204)}} \\
=\frac{7494}{\sqrt{(13607)(36300)}} \\
=\frac{7494}{\sqrt{493934100}} \\
=\frac{7494}{22224,62823} \\
=0,337193491
\end{aligned}
$$

3. Mencari koefisien determinasi

Perhitungan koefisien determinasi digunakan untuk menganalisis seberapa besar presentasi kontribusi variabel bebas terhadap variabel terikat. Perhitungan koefisien dilakukan pada hubungan antara variabel model pembelajaran tuntas dengan motivasi siswa dan metode discovery dengan motivasi siswa.

1. Koefisien determinasi variabel model pembelajaran tuntas dengan motivasi siswa sebagai berikut:

$$
\begin{aligned}
\mathrm{r}^{2} & =\frac{\mathrm{b}\left(\mathrm{n} \sum \mathrm{X}_{1} \mathrm{Y}_{1}\right)-\left(\sum \mathrm{X}_{1}\right)\left(\sum \mathrm{Y}\right)}{\mathrm{n} \sum \mathrm{Y}^{2}-\left(\sum \mathrm{Y}\right)^{2}} \\
& =\frac{0,430(24.108780-(1532)(1698))}{24(121646)-\left(1698^{2}\right)} \\
& =\frac{0,430(2610720-2601336)}{2919504-2883204} \\
& =\frac{4035,12}{36300} \\
& =0,11
\end{aligned}
$$

Jadi hubungan variabel model pembelajaran tuntas dengan variabel motivasi siswa sebesar $11 \%$

2. Koefisien determinasi variabel metode discovery dengan motivasi siswa sebagai berikut:

$$
\begin{aligned}
\mathrm{r}^{2} & =\frac{\mathrm{c}\left(\left(\mathrm{n} \sum \mathrm{X}_{2} \mathrm{Y}-\left(\sum \mathrm{X}_{2}\right)\left(\sum \mathrm{Y}\right)\right)\right)}{\mathrm{n} \sum \mathrm{Y}^{2}-\left(\sum \mathrm{Y}\right)^{2}} \\
& =\frac{0,445((24)(118677)-(1673)(1698))}{24(121646)-(1698)^{2}} \\
& =\frac{0,445(2848248-2840754)}{2919504-2883204} \\
& =\frac{3334,83}{36300} \\
& =0,092
\end{aligned}
$$


Jadi hubungan variabel metode discovery dengan variabel motivasi siswa sebesar $9,2 \%$

4. Mencari nilai korelasi ganda

Uji korelasi ganda digunakan untuk menguji hipotesis variabel model pembelajaran tuntas dan metode discovery terhadap motivasi siswa yang dilakukan secara bersamasama. Dengan perhitungan menggunakan rumus sebagai berikut:

$$
\begin{aligned}
\operatorname{Rx}_{1} \mathrm{x}_{2} \mathrm{y} & =\frac{\mathrm{b}_{1} \sum \mathrm{x}_{1} \mathrm{Y}+\mathrm{b}_{2} \sum \mathrm{X}_{2} \mathrm{Y}}{\sum \mathrm{Y}^{2}} \\
& =\frac{(0,430)(108780)+(0,445)(118677)}{121646} \\
& =\frac{46775,4+52811,265}{121646} \\
& =0,82
\end{aligned}
$$

Berdasarkan perhitungan uji korelasi ganda maka diperoleh juga nilai koefisien determinasi $\left(\mathrm{R}^{2}\right)=(0,82)^{2}=0,67 \times 100 \%=67 \%$

\section{Uji t statistik}

Uji t digunakan untuk menguji bagaimana pengaruh masing-masing variabel bebas secara sendiri-sendiri terhadap variabel terikat. Uji ini dilakukan dengan mambandingkan thitung dengan $\mathrm{t}$ tabel. Uji t menggunakan perhitungan SPSS seri 16.

\begin{tabular}{|c|c|c|c|c|c|}
\hline \multirow[b]{2}{*}{ Model } & \multicolumn{2}{|c|}{ Unstandardized Coefficients } & \multirow{2}{*}{\begin{tabular}{c|} 
Standardized \\
Coefficients
\end{tabular}} & \multirow[b]{2}{*}{$\mathrm{t}$} & \multirow[b]{2}{*}{ Sig. } \\
\hline & B & Std. Error & & & \\
\hline 1(Constant) & 8.912 & 8.848 & & 1.007 & .325 \\
\hline $\mathrm{X} 1$ & .430 & .153 & .386 & 2.819 & .010 \\
\hline $\mathrm{X} 2$ & .445 & .106 & .576 & 4.211 & .000 \\
\hline
\end{tabular}

Tabel 4.6

Tabel perhitungan uji $\mathrm{t}$

Coefficients $^{\mathrm{a}}$

a. Dependent Variable: $Y$

1. Variabel model pembelajaran tuntas terhadap motivasi siswa

Berdasarkan hasil analisis korelasi antara variabel model pembelajaran tuntas terhadap motivasi siswa pada tabel di atas menghasilkan koefisien korelasi ryx $1=0,386$ berada pada interval koefisien 0,60-0,799 dengan tingkat hubungan kuat. Koefisien signifikansi $t$ hitung $=2,819$ sedangkan $t$ tabel pada taraf kesalahan $5 \%(\alpha 0,05)=1,721$. 
Karena hasil $\mathrm{t}$ hitung $>\mathrm{t}$ tabel pada taraf kesalahan $5 \%$ maka dapat disimpulkan bahwa ada hubungan yang positif antara model pembelajaran tuntas terhadap motivasi siswa.

2. Variabel metode discovery terhadap motivasi siswa

Berdasarkan hasil analisis korelasi antara variabel metode discovery terhadap motivasi siswa pada tabel di atas menghasilkan koefisien korelasi ryx $2=0,576$ berada pada interval koefisien 0,60-0,799 dengan tingkat hubungan kuat. Koefisien signifikansi $\mathrm{t}_{\text {hitung }}=4,211$ sedangkan $\mathrm{t}$ tabel pada taraf kesalahan $5 \%(\alpha 0,05)=1,721$. Karena hasil $\mathrm{t}$ hitung $>\mathrm{t}$ tabel pada taraf kesalahan $5 \%$ maka dapat disimpulkan bahwa ada hubungan yang positif antara metode discovery terhadap motivasi siswa.

\section{Pembahasan}

1. Pengaruh model pembelajaran tuntas (X1) terhadap hasil uji motivasi siswa (Y)

Berdasarkan hasil analisis korelasi disimpulkan bahwa variabel model pembelajaran tuntas memberikan pengaruh yang positif dan signifikan terhadap motivasi sisw. Koefisien korelasi model pembelajaran tuntas terhadap motivasi siswa $r=0,11$ dengan nilai $t$ hitung 2,819. Berdasarkan hasil tersebut dapat disimpulkan bahwa ada hubungan yang positif dan signifikan. Dari hasil penelitian ini dijelaskan bahwa sebagian besar motivasi siswa menunjukan bahwa penerapan model pembelajaran tuntas oleh guru memberikan hubungan yang besar terhadap motivasi. Hal ini membuktikan bahwa guru memegang peran penting untuk mengarahkan motivasi siswa kearah yang positif sebagai hasil belajar.

Guru yang memiliki ketepatan memilih model pembelajaran yang sesuai akan berdampak baik pada proses pembelajaran yang dilaksanakan. Salah satunya dengan menerapkan model pembelajaran tuntas, guru membimbing, mendidik, memotivasi siswa untuk mendapatkan sutu pembelajaran yang benar-benar tuntas dalam hal ini tidak hanya terkait dengan hasil nilai yang diperoleh sesuai standar akan tetapi lebih mengarah pada motivasi siswa yang terbentuk kearah positif sebagai hasil dari proses belajar. Sesuai dengan pendapat Rusman (2012:133), model pembelajaran dapat dijadikan pola pilihan, artinya para guru boleh memilih model pembelajaran yang sesuai dan efisien untuk mencapai tujuan pendidikannya.

2. Pengaruh metode discovery (X2) terhadap hasil uji motivasi siswa (Y)

Berdasarkan hasil perhitungan diperoleh koefisien hubungan variabel metode discovery $\mathrm{r}=0,092$ dan bertanda positif terhadap hasil uji motivasi siswa. Berdasarkan perhitungan nilai $t_{\text {hitung }}=4,211$ sedangkan $t$ tabel 1,721 sehingga dapat disimpulkan bahwa terdapat korelasi positif dan signifikan antara metode discovery terhadap motivasi siswa kelas XI IPS SMA Negeri 1 Kupang. Hal ini membuktikan bahwa metode discovery ada hubungan yang positif dalam motivasi belajar siswa ke arah positif.

Menurut Pribadi (2011:80) metode pembelajaran merupakan cara yang digunakan oleh guru atau instuktur untuk menyampakan isi atau materi pembelajaran secara spesifik. 
Sehingga guru selalu berusaha memilih metode pengajaran yang setepat-tepatnya, yang dipandang lebih efektif daripada metode-metode lainnya sehingga kecakapan dan pengetahuan yang diberikan oleh guru itu benar-benar menjadi milik murid (Suryosubroto, 2002:148). Salah satu metode pembelajaran yang diterapkan guru SMA Negeri 1 Kupang bagi siswa kelas XI IPS SMA Negeri 1 Kupang yaitu metode discovery, memiliki hubungan yang positif terhadap pengarahan serta motivasi belajar siswa. Dengan metode discovery, guru memberi banyak waktu dan kesempatan pada siswa untuk mendapat pengalaman belajarnya.

3. Pengaruh model pembelajaran tuntas (X1) dan metode discovery (X2) terhadap hasil uji motivasi siswa (Y)

Berdasarkan hasil analisis korelasi ganda maupun pengujian hipotesis diperoleh kesimpulan bahwa variabel model pembelajaran tuntas dan metode discovery secara bersama-sama memberikan hubungan yang positif dan signifikan terhadap hasil uji motivasi siswa kelas XI IPS SMA Negeri 1 Kupang. Pemilihan model dan metode pembelajaran yang tepat oleh guru dalam pembelajaran di kelas sangat berpengaruh terhadap motivasi siswa. Variabel model pembelajaran tuntas dan metode discovery memberikan hubungan positif dan signifikan terhadap motivasi siswa kelas XI IPS SMA Negeri 1 Kupang.

\section{SIMPULAN}

Berdasarkan hasil analisis data dan pembahasan hasil penelitian dapat disimpulkan beberapa hal sebagai berikut:

1. Terdapat hubungan yang positif dan signifikan antara model pembelajaran tuntas terhadap motivasi siswa kelas XI jurusan IPS SMA Negeri 1 Kupang. Hasil analisis korelasi sederhana diperoleh koefisien korelasi parsial $\left(\mathrm{r}_{1}\right)$ variabel model pembelajaran tuntas sebesar $0,11(\mathrm{R})^{2}$ sebesar 0,67 dan bertanda positif, dengan nilai $\mathrm{t}$ hitung $=2,819$ yang berarti ada hubungan positif antara model pembelajaran tuntas terhadap hasil uji motivasi siswa.

2. Terdapat hubungan yang positif dan kurang signifikan antara metode discovery terhadap motivasi siswa kelas XI jurusan IPS SMA Negeri 1 Kupang. Hasil analisis korelasi sederhana diperoleh koefisien korelasi parsial $\left(\mathrm{r}_{2}\right)$ variabel metode discovery sebesar 0,092 (R $)^{2}$ sebesar 0,67 dan bertanda positif;. dengan nilai $\mathrm{t}_{\text {hitung }}=4,211$ yang berarti ada hubungan positif antara metode discovery terhadap hasil uji motivasi siswa.

3. Terdapat hubungan signifikan antara model pembelajaran tuntas dan metode discovery terhadap motivasi siswa kelas XI jurusan IPS SMA Negeri 1 Kupang. Hasil analisis korelasi ganda diperoleh harga $r=0,82 R^{2}=0,67$ dan nilai $t$ hitung $=4,23$. Berdasarkan hasil tersebut kuatnya hubungan model pembelajaran tuntas dan metode discovery terhadap hasil uji motivasi siswa kelas XI jurusan IPS SMA Negeri 1 Kupang. 


\section{DAFTAR PUSTAKA}

Arikunto Suharsimi. 2009. Dasar-Dasar Evaluasi Pendidikan. Jakarta: Bumi Aksara

Djamarah. 2002. Strategi Belajar Mengajar. Jakarta : Rineka Cipta.

Dimyati, Mudjiono. 2002. Belajar dan Pembelajaran. Jakarta: Rineka Cipta

Freire P dan Shor I., 1987, Menjadi guru merdeka, Yogyakarta: LKiS Yogyakarta

Kasmadi dan Nia Siti Sunariah. 2013. Panduan Modern Penelitian Kuantitatif. Bandung: Alfabeta

Kasmadi dan Nia Siti Sunariah. Panduan Modern Penelitian Kuantitatif. Bandung: Alfabeta, 2013), h. 79

Khodijah, Nyayu. 2011. Psikologi Pendidikan. Palembang: Grafika Telindo Press

Mulyatiningsih Endang. 2012. Metode Penelitian Terapan Bidang Pendidikan. Bandung: Alfabeta

Mulyasa. 2004. Implementasi Kurikulum 2004 Panduan Belajar KBK. Bandung: Remaja Rosdakarya.

Rusman. 2012. Model-model Pembelajaran: Mengembangkan profesionalisme guru. Jakarta: Rajawali Pers

Roestiyah. 2008. Strategi Belajar Mengajar. Jakarta: Rineka Cipta

Sagala Syaiful. 2010. Konsep dan Makna Pembelajaran. Bandung: Alfabeta

Suryosubroto. 2002. Proses Belajar Mengajar di Sekolah. Jakarta: Rineka Cipta

Sardiman A. M. 2014. Interaksi dan Motivasi Belajar Mengajar. Jakarta: Rajawali Pers

Yamin Martinis. 2006. Profesionalisasi Guru dan Implementasi Kurikulum Berbasis Kompetensi. Jakarta: Gaung Persada Press.

Wahab, Rohmalina. 2015. Psikologi Belajar. Jakarta: PT Raja Grafindo Persada 